\title{
Communication
}

\section{In Vitro Evaluation of Cytotoxicity and Proliferative Effects of Lyophilized Porcine Liver Tissue on HepG2 Hepatoma Cells and Adipose-Tissue-Derived Mesenchymal Stromal Cells}

\author{
Priscilla Berni ${ }^{1}$, Virna Conti ${ }^{1}$, Orlando Ferroni ${ }^{2}$, Roberto Ramoni ${ }^{1}\left[\right.$, Giuseppina Basini ${ }^{1}$ (D) \\ and Stefano Grolli ${ }^{1, *(1)}$ \\ 1 Dipartimento di Scienze Mediche Veterinarie, Università di Parma, Via del Taglio 10, 43126 Parma, Italy; \\ priscilla.berni@unipr.it (P.B.); virna.conti@unipr.it (V.C.); roberto.ramoni@unipr.it (R.R.); \\ giuseppina.basini@unipr.it (G.B.) \\ 2 Neorland $^{\circledR}, 261000$ Cremona, Italy; orlando.ferroni@libero.it \\ * Correspondence: stefano.grolli@unipr.it; Tel.: +39-052-190-2767
}

check for updates

Citation: Berni, P.; Conti, V.; Ferroni, O.; Ramoni, R.; Basini, G.; Grolli, S. In Vitro Evaluation of Cytotoxicity and Proliferative Effects of Lyophilized Porcine Liver Tissue on HepG2 Hepatoma Cells and Adipose-Tissue-Derived Mesenchymal Stromal Cells. Appl. Sci. 2021, 11, 6691. https://doi.org/ 10.3390/app11156691

Academic Editor: Anna Iwaniak

Received: 19 April 2021

Accepted: 19 July 2021

Published: 21 July 2021

Publisher's Note: MDPI stays neutral with regard to jurisdictional claims in published maps and institutional affiliations.

Copyright: (c) 2021 by the authors. Licensee MDPI, Basel, Switzerland. This article is an open access article distributed under the terms and conditions of the Creative Commons Attribution (CC BY) license (https:// creativecommons.org/licenses/by/ $4.0 /)$.

\begin{abstract}
In recent years, nutritional supplements from different sources have been widely considered to support medical treatments in patients affected by chronic hepatopathies. Their potential therapeutic benefit has been recognized, but some evidence of safety issues has been reported. Recently it has been hypothesized that the liver could produce various of bioactive factors to maintain organ homeostasis and promote tissue healing. Thus, liver-specific preparations containing bioactive factors could provide a suitable substrate for in vitro study of liver tissue maintenance/healing, as a prospective regenerative medicine approach. Furthermore, they could represent a dietary supplement or nutraceutical for adjuvant therapies when correctly prepared and formulated. This work aims to provide data about the safety and biological activity of a freeze-dried porcine liver preparation. The lyophilized powder obtained from the whole organ has been tested in term of in vitro cell cytotoxicity (MTT assay) and proliferation assays (bromo-deoxyuridine incorporation and direct cell count) in two different cell types: human hepatoma HepG2 cell line and adipose-tissue-derived canine mesenchymal stromal cells (At-MSCs). At concentration levels between 100 to $500 \mu \mathrm{g} / \mathrm{mL}$, the lyophilized liver powder stimulated mitochondrial metabolism as assessed by MTT assay $(p \leq 0.001$ for HepG2 and for At-MSCs) and induced an increase in bromo-deoxyuridine incorporation in both cell types ( $p \leq 0.01$ for HepG2 and $p<0.001$ for At-MSCs). In addition, direct cell count demonstrated a higher proliferative activity in treated At-MSCs $(p<0.001)$. Although preliminary, these data suggest that the whole-liver powder is noncytotoxic in vitro and may represent a stimulus to cell metabolism and proliferation. Further studies are needed to detect the bioactive components of the supplement and characterize in deeper detail the cellular pathways that they can modulate.
\end{abstract}

Keywords: food supplements; liver diseases; lyophilized liver extract; mesenchymal stromal cells

\section{Introduction}

Chronic liver diseases represent a serious threat to public health worldwide, characterized by significant morbidity and mortality [1]. The European Union has the most significant liver disease rate globally, with variable epidemiological characteristics among the member states [2].

Common chronic liver diseases are, for example, those of viral origin, caused mainly by hepatitis $B$ and $C$ viruses, as well as those related to alcohol abuse, which have the highest incidence in the EU [2]. In recent years, however, nonalcoholic steatohepatitis (NASH), mainly linked to obesity as a risk factor, is also continuously increasing [3]. Other less common hepatopathies are cholestatic diseases, mainly represented by primary cholangitis (PBC) and primary sclerosing cholangitis (PSC), autoimmune hepatitis, genetic 
diseases such as hemochromatosis, in addition to alpha antitrypsin deficiency and cystic fibrosis [4].

A common feature of most of these pathologies is the development of hepatic fibrosis, which can be defined as the combination of quantitative and qualitative changes in the extracellular matrix, mainly due to collagen deposition, which progresses towards the complete disorganization of the hepatic architecture [2]. This advanced stage, that is known as cirrhosis [4], is responsible for more than 1 million deaths annually [5]. Once hepatic cirrhosis is present, the patient is prone to the onset of relevant complications such as liver failure, portal hypertension or the development of hepatocellular carcinoma [4].

In recent years, various efforts have been made to identify new treatments to stop the progression of chronic liver injuries and increase their prevention. At the same time, nutritional supplements are widely used to prevent diseases, but also as adjuvants accompanying conventional therapies in patients with chronic liver diseases. For some of these supplements, studies reporting their potential therapeutic benefits are available [6], but there is growing evidence that when not correctly used these supplements are responsible for hepatotoxicity [7].

Recent advances have been made dealing with the role of tissue-specific secretome in regulating tissue homeostasis [8]. The term secretome describes a complex mixture of bioactive molecules secreted by a cell population or a tissue, including soluble molecules and extracellular vesicles, but also extracellular matrix components [9]. It is now accepted that biologically active molecules derived from a specific organ can be useful to control tissue homeostasis and regeneration. For example, the use of decellularized liver has been proposed to maintain hepatocyte functions in vitro, when used as a whole preparation (3D scaffold) or powder [10-12]. These findings point out the attention to the preparation of biological substrates able to maintain organ specific activity, both in vitro and in vivo.

In this context, a supplement derived from a minimal manipulation of porcine liver, preserving biological features of organ-specific components, could be worthy of investigation. Among the various components of the liver-derived supplements, of particular interest is the secretome released by mesenchymal stromal cells (MSCs), a population of multipotent stem cells residing in numerous tissues and organs, including the liver [13]. MSCs can release in the extracellular space a rich and complex set of bioactive molecules (the MSC secretome), consisting of a secreted soluble protein fraction, mainly constituted of cytokines and growth factors, and of a vesicular component (extracellular vesicles, EV) [14]. Both the EVs and the soluble protein components can promote tissue regeneration, modulate the immune response, have antifibrotic effects and induce neo-angiogenesis in ischemic tissues $[15,16]$.

EVs is a generic term representing a heterogeneous set of vesicles equipped with a phospholipid bilayer membrane, ranging in size from 40 to $1000 \mathrm{~nm}$. EVs include exosomes, microvesicles, and apoptotic bodies, which differ in size, composition, and biology. EVs rapidly diffuse into a tissue, releasing trophic and immunomodulating factors at the damage site, promoting tissue repair and regeneration [15].

Thanks to their ability to reach target cells, regardless of the presence of biological barriers, among the EVs, exosomes and microvesicles are the most investigated cell-free therapeutic agents in regenerative medicine [16]. Exosomes, in particular, are easily transported by biological fluids and can reach different parts of the body thanks to their size. They express various chemokine receptors and adhesion molecules that drive their homing to the site of damage or inflammation [17]. The membranes rich in cholesterol, sphingomyelin, and ceramide allow the uptake of the exosomes' contents by the target cells through the mechanism of endocytosis [15,16]. Exosomes carry nucleic acids, lipids, and proteins, including cytokines, chemokines, and growth factors. By releasing these molecules, exosomes can influence the immune response and promote tissue angiogenesis, repair, and regeneration [17]. Therefore, the EVs of MSCs represent a powerful tool capable of maintaining or renewing tissue homeostasis and interacting directly with the immune system, regulating its activity [18,19]. Interestingly, secreted factors prepared from MSCs 
derived from liver and human liver stem cells (HLSC) have been proposed as an effective stimulus to promote liver regeneration [20-22] supporting the hypothesis that the organ can contribute to its own homeostasis [22,23]. These findings suggest that liver-derived biological preparations can play an important role to study liver biology and regeneration in vitro, but also represent a potential tool to control the progression of chronic liver injuries in vivo.

The aim of this preliminary work was to assess the in vitro safety of a powder obtained through a controlled freeze-drying process of whole porcine livers [24]. The preparation method of the freeze-dried supplement was aimed at preserving the bioactive principles present in the liver tissue of healthy pigs, including soluble proteins, extracellular vesicles (EVs), extracellular matrix components, vitamins (especially of group B), but also minerals (for example iron), and essential amino acids.

Two cell types were used to evaluate the supplement cytotoxicity, the liver cell line HepG2, and primary cultures of canine MSCs derived from the adipose tissue (At-MSCs). HepG2 cells have been derived from a human hepatoma and are commonly used in drug metabolism and hepatotoxicity studies, given their ability to preserve many differentiated hepatic functions [25]. MSCs have been chosen as a primary stromal cell model playing essential roles in various tissues homeostasis and regeneration [26]. Furthermore, MSCs are actively studied for the development of cell therapy and tissue engineering strategies aimed to restore liver function [10].

\section{Materials and Methods}

\subsection{Preparation of the Porcine Liver Lyophilized Powder}

The porcine lyophilized liver powder (LLP) was provided by the company Neorland ${ }^{\circledR}$ (Cremona, Italy). Briefly, for the preparation of the powder, the porcine livers $(n>25)$ were collected at the abattoir from eight-month-old large-white $x$ landrace crossbred pigs. Both castrated male and female pigs were used. The livers were frozen soon after the collection (not more than $3 \mathrm{~h}$ ), with controlled lowering of the temperature. The livers were then freeze-dried and ground to obtain a lyophilized liver powder. The freeze-drying was performed using a proprietary procedure created by the producer, based on different steps of temperature lowering.

\subsection{Solubilization of the Porcine Liver Lyophilized Powder}

The solubilization of the LLP was performed by dissolving $2 \mathrm{mg}$ of powder/mL of Dulbecco's Modified Eagle's Medium (DMEM), supplemented with penicillin (100 UI/mL), streptomycin $(100 \mu \mathrm{g} / \mathrm{mL})$, by four sonication cycles (Microson XL, Misonix) of $5 \mathrm{~s}$ each, placing the suspension in ice for $5 \mathrm{~min}$ between the cycles. Then, enzymatic digestion was performed by type I collagenase $(0.1 \mathrm{mg} / \mathrm{mL})$ by two hours incubation at $37^{\circ} \mathrm{C}$ in mild agitation. After digestion, the suspension was centrifuged for $10 \mathrm{~min}$ at $10,000 \times \mathrm{g}$ to pellet and discard undigested residues. A control sample was prepared without collagenase digestion. The use of collagenase digestion was introduced to improve the release of protein and bioactive components by the liver powder. The protein content of the suspensions was determined by BCA protein assay kit (Pierce), following the instructions of the provider.

Different protein concentrations were used to evaluate in vitro LLP activity on cell lines, corresponding to $10 \mu \mathrm{g}, 50 \mu \mathrm{g}, 100 \mu \mathrm{g}, 200 \mu \mathrm{g}, 500 \mu \mathrm{g}$, and $1000 \mu \mathrm{g}$ of undigested LLP per treatment. The actual protein content of each treatment is reported in the Results section, at Section 3.1.

\subsection{In-Vitro Cell Culture}

The liver cell line HepG2 (human hepatocellular carcinoma) and primary cultures of canine adipose-tissue-derived mesenchymal stromal cells (At-MSCs) were used as in vitro experimental models. All reagents were purchased from Thermo Fisher Scientific, (Milan, Italy) unless indicated. 
HepG2 cell line culture: Frozen cells were thawed at $37^{\circ} \mathrm{C}$ and then plated into $25 \mathrm{~cm}^{2}$ flask containing complete DMEM (cDMEM), consisting of DMEM supplemented with 10\% FBS, penicillin (100 UI/mL), and streptomycin $(100 \mu \mathrm{g} / \mathrm{mL})$. The medium was changed every $48 \mathrm{~h}$. Cells were detached by trypsinization when reached about $80 \%$ confluence and re-seeded at 1:4 ratio.

Canine adipose-tissue-derived mesenchymal stromal cells preparation: Adipose tissue samples were collected from donors during elective surgery at the Veterinary Hospital of the University of Parma. An informed consensus was signed by the owners. The tissue samples were stored in complete phosphate-buffered saline solution (cPBS) containing penicillin $(100 \mathrm{U} / \mathrm{mL})$, streptomycin $(100 \mu \mathrm{g} / \mathrm{mL})$, and amphotericin $\mathrm{B}(2.5 \mu \mathrm{g} / \mathrm{mL})$ before being processed (maximum $2 \mathrm{~h}$ ). A total 1-1.5 g of adipose tissue was fragmented in $0.3-0.5 \mathrm{~cm}^{3}$ pieces by means of a sterile scalpel under a cell culture hood. The tissue was then transferred to a $15 \mathrm{~mL}$ conical centrifuge tube containing a solution of $0.1 \%$ $w / v$ collagenase type I, prepared in DMEM, supplemented with $50 \mathrm{U} / \mathrm{mL}$ penicillin and $20 \mu \mathrm{g} / \mathrm{mL}$ streptomycin, at a ratio of $5 \mathrm{~mL}$ of medium per gram of minced tissue. The enzymatic digestion was carried out at $37^{\circ} \mathrm{C}$, in mild agitation for $60 \mathrm{~min}$. The cell suspension was then filtered through a nylon filter (mesh $100 \mu \mathrm{m})$ and centrifuged at $190 \times g$ per $15 \mathrm{~min}$. The cell pellet was resuspended in $3 \mathrm{~mL}$ of complete medium (cDMEM), consisting of low-glucose DMEM supplemented with $10 \% v / v$ FBS, penicillin $100 \mathrm{U} / \mathrm{mL}$, streptomycin $100 \mu \mathrm{g} / \mathrm{mL}$, amphotericin B $2.5 \mu \mathrm{g} / \mathrm{mL}$; and then seeded in $25 \mathrm{~cm}^{2}$ culture flasks. The cells were maintained in an incubator at $37^{\circ} \mathrm{C}$ in $5 \% \mathrm{CO}_{2}$ atmosphere, renewing the medium every $72 \mathrm{~h}$. When the cells reached about $80 \%$ of confluence, they were detached using $0.05 \%$ Trypsin-EDTA in cPBS and reseeded at 10,000 cells $/ \mathrm{cm}^{2}$. The cells were then expanded until P3, when they were used for the experiments described below. When needed, cells were cryopreserved in liquid nitrogen using a freezing medium consisting of $50 \%(v / v)$ FBS, $10 \%(v / v)$ dimethyl sulfoxide, and 40\% DMEM $(v / v)$.

\subsection{Cell Cytotoxicity and Proliferation Assay}

For the evaluation of the effects of the LLP on cell metabolic activity and proliferation, the MTT assay and bromo-deoxyuridine (BrdU) incorporation assays were performed. The MTT test is a colorimetric assay based on the ability of mitochondrial oxidoreductase enzymes to convert MTT (3-(4,5-dimethylthiazol-2-yl)-2,5-diphenyltetrazolium bromide), a soluble, colorless reagent, into purple formazan crystals, whose formation can be quantified by spectrophotometric techniques. The production of insoluble salts derived from MTT is proportional to mitochondrial metabolic activity. The MTT assay is widely used to study cell viability, proliferation, and cytotoxicity. However, since the treatment can alter cell metabolic activity without altering cell replication, the MTT assay was associated with bromo-deoxyuridine (BrdU) incorporation assay, a more specific test for the quantification of cell replication. A direct cell count was also performed to evaluate cell replication in the presence of LLP.

\subsection{MTT Assay}

For the MTT assay, HepG2 and At-MSCs were seeded in 96-well plates at a density of $1 \times 10^{4}$ cells/well in $200 \mu \mathrm{l}$ of cDMEM. After $24 \mathrm{~h}$, cells were treated with 10, 50, 100, 200, 500, or $1000 \mu \mathrm{g}$ of LLP suspension per well, also maintaining an untreated control (for the effective protein content of each treatment see Section 3.1). After $48 \mathrm{~h}$ treatment, $20 \mu \mathrm{L}$ of MTT (5 mg/mL in saline solution) were added in each well. After $4 \mathrm{~h}, 100 \mu \mathrm{L}$ of the solubilization solution ( $10 \%$ sodium dodecyl sulphate in $\mathrm{HCl} 0.01 \mathrm{M}$ ) was added and plates were then maintained at $37^{\circ} \mathrm{C}$ overnight. The formation of tetrazolium salts was evaluated by spectrophotometry at $570 \mathrm{~nm}$, using a reference wavelength of $630 \mathrm{~nm}$. In each experiment, six replicates were prepared for both control and treatment. The experiment was repeated at least five times for each cell line. For At-MSC, seven different cell preparations were analyzed at P3. To evaluate metabolic activity of HepG2 cells in cultures supplemented with LLP alone, cells were seeded in 96-well plates at a density of 
$1 \times 10^{4}$ cells /well in $200 \mu \mathrm{L}$ of serum-free DMEM. After $24 \mathrm{~h}$, cells were treated with 10 , $50,100,200,500$, or $1000 \mu \mathrm{g}$ of LLP suspension per well, maintaining an untreated control. Cells cultured with DMEM containing 10\% FBS supplementation were considered as a positive control. MTT assay was performed after $48 \mathrm{~h}$ treatment. The experiment was repeated three times. For this set of experiments, LLP solubilization was performed as described in Section 2.2, avoiding the digestion step with type I collagenase.

\subsection{Bromo-Deoxyuridine Incorporation Assay}

Cell proliferative capacity was analyzed by evaluating the ability of treated cells to synthesize DNA after exposure to LLP. DNA synthesis was measured by quantifying the incorporation of bromo-deoxyuridine (BrdU) as a thymidine analogue, using an immunoenzymatic assay. An increase in Brdu incorporation corresponds to an increase in the DNA synthesis that is correlated to the cell replicative activity.

For the BrdU assay, HepG2 and AT-MSCs were grown as described above for the MTT assay. Cells were treated with 200 or $500 \mu \mathrm{g}$ of LLP suspension per well and untreated wells were used as control. The cell proliferation Elisa BrdU kit (Roche Diagnostic, Monza, Italy) was performed following manufacturer's instructions. The incorporation of BrdU was evaluated in three different experiments for each cell line, preparing four replicates for each treatment. Three different primary cultures of At-MSCs were used at P3.

\subsection{Direct Cell Count}

To evaluate HepG2 and At-MSC growth after treatment with the liver powder (control, $100,200$, and $500 \mu \mathrm{g}), \mathrm{P} 3-\mathrm{P} 4$ cells were seeded at a density of 5000 cells $/ \mathrm{cm}^{2}$, in $35 \mathrm{~mm}$ diameter Petri dishes. After $72 \mathrm{~h}$, cells were trypsinized and then counted in a Burker chamber. Cell vitality was assessed by Trypan Blue assay. Cell-doubling number (CDn) and cell-doubling time (DT) were calculated as suggested by Suelzu et al. [27]. The two parameters were evaluated as follows: $\mathrm{CD}=\ln (\mathrm{Nf} / \mathrm{Ni}) / \ln (2) ; \mathrm{DT}=\mathrm{CT} / \mathrm{CD} n$.

Three replicates were prepared and counted for each tested concentration. The experiment was repeated three times for HepG2 cells, while four different At-MSC populations were evaluated.

\subsection{Statistical Analysis}

Experimental data are presented as mean SEM; statistical differences between treatments were calculated with ANOVA using the Statgraphics package (STSC Inc., Rockville, MD, USA). When significant differences were found, means were compared by Scheffè's $\mathrm{F}$ test; $p$ values $<0.05$ were considered statistically significant.

\section{Results}

\subsection{Protein Content of the Solution of LLP}

The protein contents of the LLP solutions used for the in vitro experiments that had been initially prepared as $2 \mathrm{mg} / \mathrm{mL}$ suspensions of the lyophilized powder, were evaluated by BCA protein assay kit. The average protein content was determined both in nondigested and collagenase-digested LLP suspension $(n=3)$. The average protein content was $0.81 \pm 0.13 \mathrm{mg} / \mathrm{mL}$ for the samples that were not treated with the type I collagenase, while it was $1.1 \pm 0.4 \mathrm{mg} / \mathrm{mL}$ for the samples that were treated with the enzyme, with a statistically significant increase after enzyme digestion $(p<0.01)$. Thus, the effective mean soluble protein content was $55 \pm 20,110 \pm 40$, and $275 \pm 100 \mu \mathrm{g} / \mathrm{mL}$ respectively for the $100 \mu \mathrm{g}, 200 \mu \mathrm{g}$, and $500 \mu \mathrm{g}$ treatments prepared following collagenase digestion (see Sections 3.2 and 3.3). A mean 35.8\% increase in protein content was observed after collagenase treatment, confirming that the collagenase digestion improves the release of proteins by the liver lyophilizate. Since we performed preliminary experiments that demonstrated that the collagenase was inactivated by the FBS present in the cDMEM (data not shown), both cytotoxicity and proliferation assays were performed with the LLP digested with collagenase. 


\subsection{Cell Cytotoxicity}

Cell metabolic activity of HepG2 and canine At-MSCs in response to LLP treatment was evaluated by MTT test. A statistically significant stimulatory effect was observed for both cell lines ( $p<0.01$ for HepG2; $p<0.001$ for At-MSCs; Figure 1). With regards to HepG2, stimulation occurred at $100 \mu \mathrm{g}$ of LLP $(p<0.01)$, while lower points were not different from control cultures. The 200 and $500 \mu \mathrm{g}$ LLP treatments induced a stronger effect with respect to $100 \mu \mathrm{g}$, although no significant difference was observed between the treatments (Figure 1A). At the higher tested point $(1000 \mu \mathrm{g})$ a decrease in the effect was observed, suggesting that a plateau was reached at $500 \mu \mathrm{g}$. A higher stimulation was observed on the At-MSCs (Figure 1B; $p<0.001$ ). The treatment with $200 \mu \mathrm{g}$ of LLP showed the stronger effect. Although no statistically significant difference was demonstrated between the treatments ranging from $100 \mathrm{ug}$ to $1000 \mathrm{ug}$, a decreasing MTT signal was observed starting at $500 \mu \mathrm{g}$, suggesting a tendency towards decrease in the stimulatory effect in response to higher LLP levels. No cytotoxic effects were observed on HepG2 and At-MSCs for the LLP concentration tested.
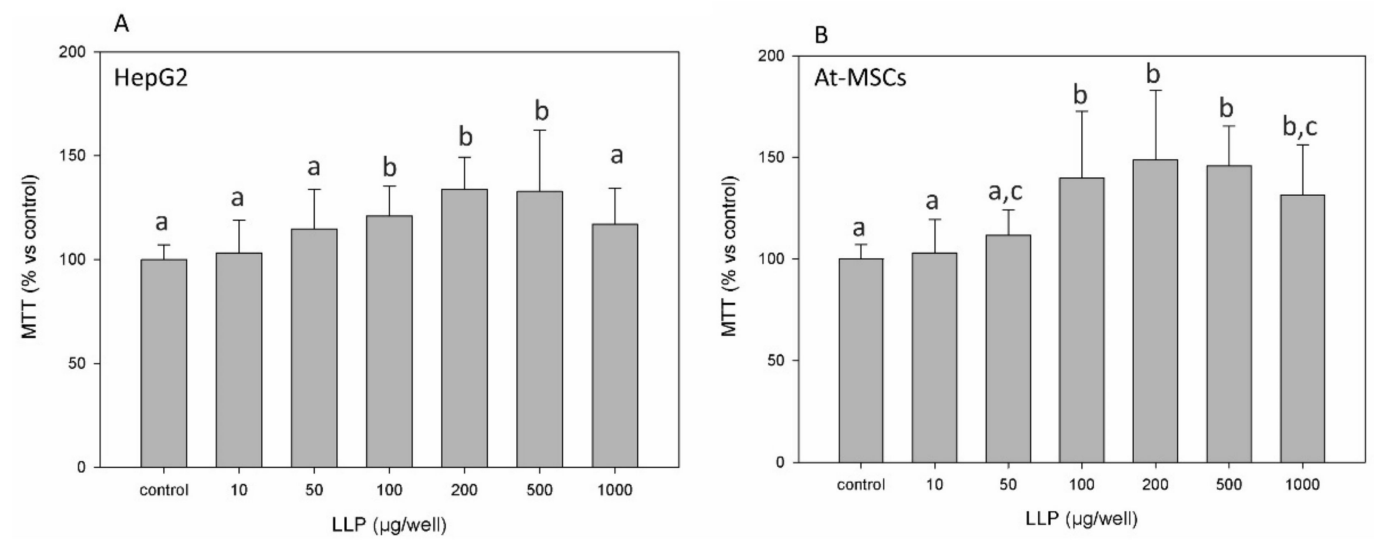

Figure 1. MTT assay on HepG2 and At-MSC cultures after LLP treatment (48 h). (A) HepG2: LLP treatment ranging from $100 \mu \mathrm{g}$ to $500 \mu \mathrm{g} /$ well increased the MTT signal with respect to the control $(p<0.001)$. (B) At-MSCs: a statistically significant improvement of MTT conversion was observed at concentrations of LLP ranging from $100 \mu \mathrm{g}$ to $1000 \mu \mathrm{g}(p<0.001)$. Absence of a common letter means a statistically significant difference $(p<0.001)$.

The ability of LLP to maintain HepG2 metabolic activity was evaluated by MTT assay also in serum-free medium. A statistically significant increase $(p<0.001)$ in MTT conversion was observed in the range of treatment between $200 \mu \mathrm{g}$ and $1000 \mu \mathrm{g}$ (Figure 2). Interestingly, in this range, the potency of LLP was not different in comparison to the supplementation of HepG2 cultures with 10\% FBS. 


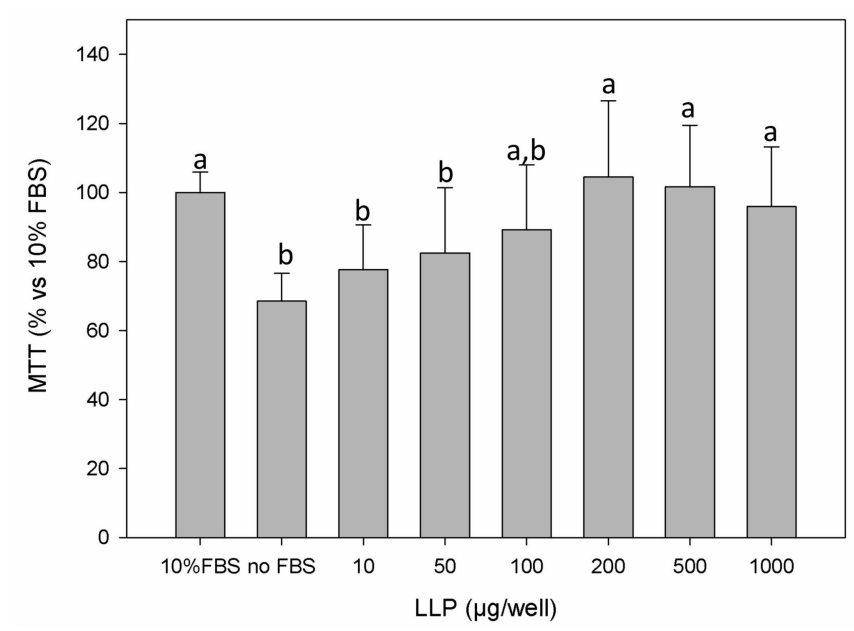

Figure 2. MTT assay on HepG2 after LLP treatment (48 h) in serum-free medium. LLP treatments ranging from $200 \mu \mathrm{g}$ to $1000 \mu \mathrm{g} /$ well increased the MTT signal with respect to serum-free control cultures $(p<0.001)$. A dose-dependent trend was observed; higher concentrations of LLP demonstrated an effect comparable to $10 \%$ FBS supplementation. Absence of a common letter means a statistically significant difference $(p<0.001)$.

\subsection{Cell Proliferation: Brdu Incorporation Assay}

Since the MTT test demonstrated an increase in metabolic activity of both cell lines, a cell proliferation assay based on bromo-deoxyuridine incorporation in the DNA of proliferating cells was performed. A different response was observed between the HepG2 cell line and canine At-MSCs after the treatment.

The analysis of the DNA synthesis in HepG2 in response to LLP treatment, revealed a more complex picture compared to that of the At-MSCs (Figure 3A). The treatment with $200 \mu \mathrm{g} /$ well of LLP digested with collagenase showed a moderate but statistically significant stimulatory effect $(p<0.01)$ compared to the control, while the cells treated with the higher concentrations $(500 \mu \mathrm{g})$ showed a replicative activity similar to that of the control.
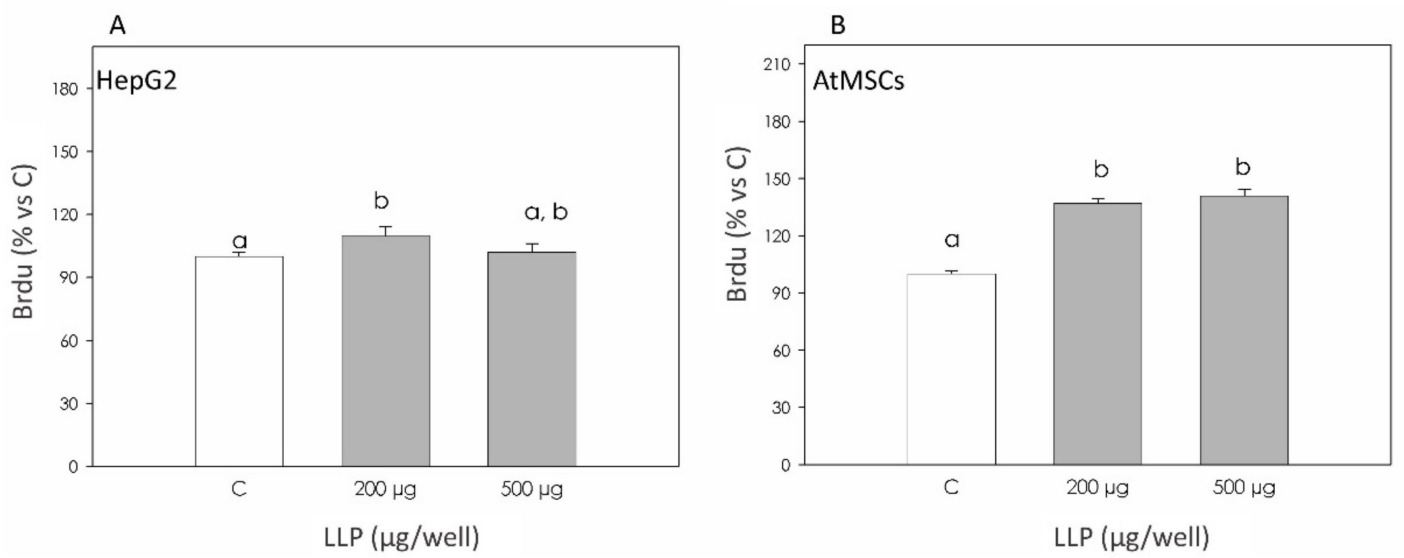

Figure 3. Evaluation of BrdU incorporation in HepG2 and At-MSCs after LLP treatment (A) HepG2: treatment with a suspension prepared with $200 \mu \mathrm{g}$ of LLP increased DNA synthesis $(p<0.01)$, while $500 \mu \mathrm{g} / \mathrm{mL}$ showed no difference in comparison to the control. (B) At-MSCs: both 200 and $500 \mu \mathrm{g}$ of LLP induced an increase in BrdU incorporation $(p<0.001)$. Different letters indicate statistically significant differences.

The LLP significantly increased the At-MSCs' proliferative capacity at both tested concentrations (200 $\mu \mathrm{g} /$ well and $500 \mu \mathrm{g} /$ well; $p<0.001$; Figure 3B). The treatments induced a similar stimulating effect, thus indicating a probable saturation of the cellular response already at the lower concentration. 


\subsection{Cell Proliferation: Direct Cell Count}

As observed for the BrdU incorporation assay, direct cell count demonstrated a different response in HepG2 and At-MSCs when expanded in the presence of LLP.

Concerning HepG2 cells, although the average cell count was higher for $100 \mu \mathrm{g}$ and $200 \mu \mathrm{g}$ treatments, no statistically significant differences were observed between control and treated cultures (Figure 4A; Table 1). Cell-doubling time and cell-doubling number were not affected by cell treatments. Instead, LLP supplementation significantly improved the number of cultured At-MSCs after $72 \mathrm{~h}$, with respect to untreated cell cultures (Figure 4B; Table 2), for each of the three different concentrations tested $(p<0.001)$. No significant differences were observed between the treatments with 200 and $500 \mu \mathrm{g}$, suggesting that the treatment reached a plateau. Accordingly, At-MSCs' cell-doubling times were significantly reduced $(p<0.001)$ and cell-doubling number significantly increased following the three treatments compared to the control cultures (Table 2), suggesting a stimulatory effect of LLP on At-MSC replication.
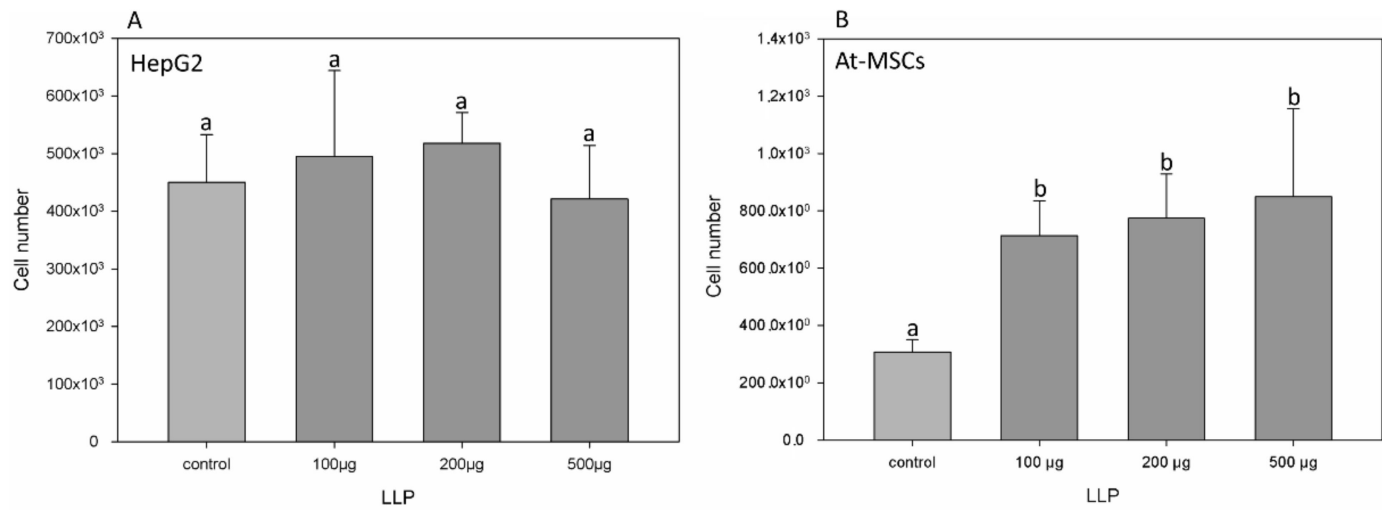

Figure 4. Direct cell count of HepG2 and At-MSCs after LLP treatment: (A) HepG2: no statistically significant difference was observed for average cell number following LLP treatment ranging from $100 \mu \mathrm{g}$ to $500 \mu \mathrm{g}$; (B) At-MSCs: following treatment with 100, 200, and $500 \mu \mathrm{g}$ of LLP, a statistically significant increase in cell number was observed $(p<0.001)$. Different letters indicate statistically significant differences.

Table 1. Average cell number, cell-doubling time, and cell-doubling number of HepG2 cells treated with different LLP amounts (100 to $500 \mu \mathrm{g})$. No statistically significant differences were observed for average cell number, cell-doubling time, and cell-doubling number for the different treatments compared to untreated control cultures.

\begin{tabular}{ccccc}
\hline HepG2 & \multicolumn{3}{c}{ Treatment } \\
\cline { 2 - 5 } & Control & $\mathbf{1 0 0} \boldsymbol{\mu g}$ & $\mathbf{2 0 0} \boldsymbol{\mu g}$ & $\mathbf{5 0 0} \boldsymbol{\mu g}$ \\
\hline Average Cell Number \pm SD & $450,000 \pm 82,585$ & $495,000 \pm 148,951$ & $517,833 \pm 53,504$ & $421,185 \pm 92,766$ \\
Average Doubling Time \pm SD & $22.51 \pm 1.87$ & $21.95 \pm 3.02$ & $21.03 \pm 0.91$ & $23.35 \pm 2.63$ \\
Average Cell-Doubling Number \pm SD & $3.21 \pm 0.27$ & $3.31 \pm 0.45$ & $3.43 \pm 0.15$ & $3.10 \pm 0.36$ \\
\hline
\end{tabular}

Table 2. Average cell number, cell-doubling time, and cell-doubling number of At-MSCs treated with different LLP amounts $(100$ to $500 \mu \mathrm{g})$. Treatments significantly increased the average cell number and cell-doubling number $(p<0.001)$ compared to control cultures, while cell-doubling time was significantly lower for treated cells $(p<0.001)$. No differences were observed between different treatments.

\begin{tabular}{ccccc}
\hline \multirow{2}{*}{ At-MSCs } & \multicolumn{3}{c}{ Treatment } \\
\cline { 2 - 5 } & Control & $\mathbf{1 0 0} \boldsymbol{\mu g}$ & $\mathbf{2 0 0} \boldsymbol{\mu g}$ & $\mathbf{5 0 0} \boldsymbol{\mu g}$ \\
\hline Average Cell Number \pm SD & $306,986 \pm 43,236$ & $713,373 \pm 121,459$ & $773,736 \pm 154,696$ & $848,833 \pm 307,133$ \\
Average Doubling Time \pm SD & $27.09 \pm 1.9$ & $18.62 \pm 1.15$ & $18.14 \pm 1.52$ & $18.01 \pm 2.82$ \\
Average Cell-Doubling Number \pm SD & $2.7 \pm 0.19$ & $3.86 \pm 0.26$ & $3.99 \pm 0.33$ & $4.1 \pm 0.68$ \\
\hline
\end{tabular}




\section{Discussion}

In recent years, intensive efforts have been made to identify new treatments to stop chronic hepatopathies' progression and improve their prevention. The possible options also include dietary supplements and nutraceuticals [28,29]. These products are commonly used worldwide, both as a supplement to conventional drug therapies and as a replacement for them.

However, there is a dispute about the real therapeutic effect of food supplements and considering the increasing use of these products both in the US and in the EU [7,30-33], their possible hepatotoxicity is an issue that is increasingly worrying the scientific community. The main difficulty in evaluating the real therapeutic action of these supplements lies in the qualitative and quantitative variability of their components. There is a broad spectrum of food supplements of different nature and origin. They are often produced from natural herbs or prepared as mixtures of biologically active substances such as vitamins, minerals, amino acids, and/or proteins. In some cases, they can sometimes contain anabolic steroids or other synthetic compounds, potentially harmful to the liver [33]. Since the liver is the organ responsible for the inactivation of most toxins from the body, some of the components of the supplements and their metabolites can cause damage at different degrees, such as cellular stress, mitochondrial inhibition, and immune reactions [34]. In addition to the risk associated with the components of the food supplements, some other factors increase the risk of the onset of hepatotoxicity, including older age, female sex, high dosage, malnutrition, alcohol abuse, genetic factors, interactions with other drugs, or the presence of concomitant diseases $[35,36]$. The clinical symptoms presentation and severity can be extremely variable, starting from mild hepatitis up to acute liver failure [37]. Furthermore, these supplements are generally administered without a prescription or specific medical advice and without monitoring over time. Moreover, unlike conventional drugs, food supplements' safety and efficacy are not always well-defined and or/declared by the producer [7].

In the last years, liver extract has been investigated as a drug for improving liver functions and restoring homeostasis in chronic liver diseases [38]. Most of the studies have been performed in vitro or in animal experimental models aimed to demonstrate the role of liver-specific environment on tissue homeostasis and regeneration. Since hepatocytes' specific characteristics are lost when cells are removed from their native environment, the identification of biological substrates or supplement resembling the liver environment is an active field of research aimed at ensuring proper cell growth, differentiation and, in perspective, organ reconstruction [10]. Liver extracts are a complex mixture of bioactive factors: soluble molecules (proteins, low-molecular-weight nutrients, vitamins, microelements), extracellular matrix components, and more complex supra-molecular structures such as exosomes and microvesicles [10,22]. Recent findings suggest that the liver itself produces a secretome endowed with anti-inflammatory properties [22]. In this context, a supplement based on liver from healthy animals could be worthy of analysis [39], both as nutraceutical and substrate for studying hepatocyte biology. The aim of this work was the preliminary assessment of the in vitro bioactivity and safety of a freeze-dried liver preparation of porcine origin.

The lyophilized liver powder's (LLP's) effects on metabolic and proliferative activity have been evaluated on two cell lines: the human-derived immortalized HepG2 hepatic cell line and the primary culture of mesenchymal stromal cells (MSCs) derived from adipose tissue (At-MSCs). The HepG2 cell line represents a model widely used by scientific literature to evaluate hepatocyte biology in vitro since it maintains many differentiated hepatic functions [25]. The use of primary liver cell cultures is quite complex since they lose most of their characteristic functions when expanded in vitro. The HepG2 cell line maintains many differentiated hepatic functions and is a widely used in vitro model in the study of hepatocyte biology [25]. MSCs, on the other hand, are cells involved in the maintenance of tissue homeostasis, control of inflammatory processes, and regeneration of damaged tissues [40]. MSCs are distributed in all tissues of mesenchymal origin and play 
their trophic and control role towards other cells in physiological conditions, as well as in various diseases [41]. MSCs have demonstrated a multi-differentiative capacity that has also been observed towards the hepatocyte lineage, thus suggesting their application in treating liver diseases using tissue engineering and regenerative medicine approaches [10]. Biological preparations derived from liver tissue can provide adequate biochemical cues to maintain hepatic functions [10,11,42]. In particular, Sellaro et al. [11] demonstrated that porcine-liver-derived powder maintained primary hepatocyte function in vitro at levels comparable to Matrigel, considered the most helpful substitute to maintain hepatic cells biological features in vitro. Concerning this, it has recently been proposed that liver extracts can modulate the hepatocyte differentiation of At-MSCs, suggesting an interplay between hepatic tissue and MSCs [43].

The colorimetric MTT assay was used to assess the cellular metabolic activity in response to LLP treatment. The results indicate that, although the effect is more potent on At-MSCs, the LLP exerts a statistically significant trophic effect on both cell lines. Since MTT assay is based on the measurement of mitochondrial respiration [44], it does not provide direct information about the replication activity of the cultured cells (i.e., it cannot be considered a direct test of cell proliferation); it rather allowed evaluation of the lack of cytotoxicity of the LLP on these cell lines at the different concentration tested. Although a precise dose-effect curve could not be determined, the effect reached saturation at treatment with 200-500 $\mu$ g of LLP for both cell lines, while the MTT signal was slightly lower at $1000 \mu \mathrm{g}$. Interestingly, a dose-response relationship was observed for HepG2 cells expanded in serum-free medium supplemented with LLP. In this case, exposure to 200, 500, and $1000 \mu \mathrm{g}$ of the powder induced a cellular metabolic activity comparable to what was observed for culture medium supplemented with 10\% FBS.

The bromo-deoxyuridine (BrdU) incorporation assays confirmed a direct effect of the LLP on the in vitro replication of HepG2 and At-MSCs, although a difference was observed between the two cell types. Regarding the HepG2 cell line, a stimulatory effect was observed only for the treatment with $200 \mu \mathrm{g}$, while no effect was present with the $500 \mu \mathrm{g}$ of LLP treatment. A more evident effect was observed on At-MSCs, where both 200 and $500 \mu \mathrm{g}$ LLP supplementation induced a significant stimulus on DNA synthesis. Since no difference was observed between the dosages, it can be hypothesized that a plateau effect had already been reached with the $200 \mu \mathrm{g}$ treatment. To confirm the effects of LLP on cell proliferation, direct cell counts were performed after treating the two cell lines with 100, 200, and $500 \mu \mathrm{g}$. The results underlined a different response of cells to LLP. While a limited, not statistically significant, increase in cell number was observed for HepG2 treated with 100 and $200 \mu \mathrm{g}$, a statistically significant increase was observed in At-MSCs for the three different concentrations tested $(p<0.001)$. Furthermore, the cell-doubling time was significantly lower for At-MSCs treated with LLP, confirming its stimulatory effect on cell proliferation. Direct cell count excluded a cytotoxic effect on both cell lines.

Taken together, the experimental results indicate that the liver lyophilized powder of porcine origin is not cytotoxic on either of the two cell types. LLP instead determines a positive metabolic (evaluated by MTT assay) and replicative (measured by DNA synthesis) stimulus to HepG2 and At-MSCs, while a statistically significant increase in cell number was observed only in At-MSC cultures. Although our data do not provide information regarding the components of the LLP responsible for these effects, recent contributions from the literature, in addition to vitamins, minerals, and other bioactive molecules, emphasize the presence in liver tissue of more complex multi-molecular particles, such as exosomes and microvesicles capable of controlling and stimulating the metabolic activity of the organ both in physiological and pathological conditions $[45,46]$. Interestingly, it has been observed that exosomes derived from liver cells modulate various biological activities (such as control of cell proliferation and apoptosis, regulation of gene transcription) on cultured hepatocytes [47] and other cell types [43]. Furthermore, the maintenance of hepatocytespecific functions of primary cultures expanded in the presence of liver extracellular matrix $[11,42]$ has been observed, suggesting that that liver tissue extracts can support 
in vitro hepatocyte culture and could be considered a candidate for the development of treatment for liver diseases [42].

Our results indicate that a porcine liver lyophilized powder derived from the whole organ without any chemical treatment is safe and maintains an in vitro stimulatory effect on HepG2 and At-MSC, although a different response was observed for the two cell types. Interestingly, the LLP stimulates proliferation in At-MSCs, in agreement with other results indicating a reciprocal cross-talk between liver cells and MSCs $[21,38]$. The work has some weak points that need to be addressed in the future. We are aware that our results do not evaluate the effect of the LLP on biological features typical of hepatocytes (glycogen, urea, and albumin synthesis) or MSCs (differentiation ability, immunomodulation, secretome production). Furthermore, the effects of LLP on other cell types, such as, for example immune cells, should be evaluated to explore a possible role of the preparation in the complex biological pathways involved in tissue maintenance and regeneration.

In conclusion, we think that the liver lyophilized powder prepared from whole porcine organs deserves a more extensive study to elucidate on one side its specific composition in terms of bioactive molecules, and on the other, to define their roles in the complex metabolic activity of hepatic tissue.

Author Contributions: Conceptualization, S.G., P.B., O.F.; methodology, S.G., V.C., P.B., O.F., R.R.; software, G.B.; validation, S.G., R.R., G.B.; formal analysis, G.B., S.G.; data curation, S.G., P.B.; writing-original draft preparation, P.B., S.G.; writing—review and editing, P.B., S.G., R.R., G.B.; visualization, P.B., S.G. All authors have read and agreed to the published version of the manuscript.

Funding: This research was partially funded by the company GUNA spa (Italy).

Institutional Review Board Statement: The study did not involve humans or animals.

Informed Consent Statement: The study did not involve humans.

Conflicts of Interest: O.F. is the sole shareholder of Neorland ${ }^{\circledR}$, which provided the lyophilized liver powder. The procedure for the liver powder preparation is protected by secrecy. O.F. contributed to the conceptualization of the study. GUNA spa partially funded the study. GUNA had no role in the design of the study; in the collection, analysis, or interpretation of the data, as well as in writing the manuscript, or in the decision to publish the results.

\section{References}

1. Mokdad, A.A.; Lopez, A.D.; Shahraz, S.; Lozano, R.; Stanaway, J.; Murray, C.J.L.; Naghavi, M. Liver cirrhosis mortality in 187 countries between 1980 and 2010: A systematic analysis. BMC Med. 2014, 12, 1-24. [CrossRef]

2. Pimpin, L.; Cortez-Pinto, H.; Negro, F.; Corbould, E.; Lazarus, J.; Webber, L.; Sheron, N. Burden of liver disease in Europe: Epidemiology and analysis of risk factors to identify prevention policies. J. Hepatol. 2018, 69, 718-735. [CrossRef]

3. Younossi, Z.M.; Marchesini, G.; Pinto-Cortez, H.; Petta, S. Epidemiology of Nonalcoholic Fatty Liver Disease and Nonalcoholic Steatohepatitis: Implications for Liver Transplantation. Transplantation 2019, 103, 22-27. [CrossRef]

4. Lemoinne, S.; Friedman, S.L. New and emerging anti-fibrotic therapeutics entering oralready in clinical trials in chronic liver diseases. Curr. Opin. Pharmacol. 2019, 49, 60-70. [CrossRef] [PubMed]

5. Rowe, I.A. Lessons from Epidemiology: The Burden of Liver Disease. Dig. Dis. 2017, 35, 304-309. [CrossRef]

6. Hanje, A.J.; Fortune, B.; Song, M.; Hill, D.; McClain, C. The Use of Selected Nutrition Supplements and Complementary and Alternative Medicine in Liver Disease. Nutr. Clin. Pract. 2006, 21, 255-272. [CrossRef]

7. Navarro, V.J.; Khan, I.; Björnsson, E.; Seeff, L.B.; Serrano, J.; Hoofnagle, J.H. Liver injury from herbal and dietary supplements. Hepatology 2017, 65, 363-373. [CrossRef]

8. Feizi, A.; Gatto, F.; Uhlen, M.; Nielsen, J. Human protein secretory pathway genes are expressed in a tissue-specific pattern to match processing demands of the secretome. NPJ Syst. Biol. Appl. 2017, 3, 1-9. [CrossRef]

9. Driscoll, J.; Patel, T. The mesenchymal stem cell secretome as an acellular regenerative therapy for liver disease. J. Gastroenterol. 2019, 54, 763-773. [CrossRef] [PubMed]

10. Zhang, J.; Chan, H.F.; Wang, H.; Shao, D.; Tao, Y.; Li, M. Stem cell therapy and tissue engineering strategies using cell aggregates and decellularized scaffolds for the rescue of liver failure. J. Tissue Eng. 2021, 12. [CrossRef]

11. Sellaro, T.L.; Ranade, A.; Faulk, D.M.; McCabe, G.P.; Dorko, K.; Badylak, S.F.; Strom, S. Maintenance of Human Hepatocyte Function In Vitro by Liver-Derived Extracellular Matrix Gels. Tissue Eng. Part A 2010, 16, 1075-1082. [CrossRef]

12. Soto-Gutierrez, A.; Zhang, L.; Medberry, C.; Fukumitsu, K.; Faulk, D.; Jiang, H.; Reing, J.; Gramignoli, R.; Komori, J.; Ross, M.; et al. A Whole-Organ Regenerative Medicine Approach for Liver Replacement. Tissue Eng. Part C Methods 2011, 17, 677-686. [CrossRef] 
13. Wang, Y.; Yu, X.; Chen, E.; Li, L. Liver-derived human mesenchymal stem cells: A novel therapeutic source for liver diseases. Stem Cell Res. Ther. 2016, 7, 71. [CrossRef]

14. Beer, L.; Mildner, M.; Ankersmit, H.J. Cell secretome based drug substances in regenerative medicine: When regulatory affairs meet basic science. Ann. Transl. Med. 2017, 5, 170. [CrossRef]

15. Maguire, G. Stem cell therapy without the cells. Commun. Integr. Biol. 2013, 6, e26631. [CrossRef]

16. Vishnubhatla, I.; Corteling, R.; Stevanato, L.; Hicks, C.; Sinden, J. The Development of Stem Cell-Derived Exosomes as a Cell-Free Regenerative Medicine. J. Circ. Biomark. 2014, 3. [CrossRef]

17. Harrell, C.R.; Fellabaum, C.; Jovicic, N.; Djonov, V.; Arsenijevic, N.; Volarevic, V. Molecular Mechanisms Responsible for Therapeutic Potential of Mesenchymal Stem Cell-Derived Secretome. Cells 2019, 8, 467. [CrossRef]

18. Fierabracci, A.; Del Fattore, A.; Luciano, R.; Muraca, M.; Teti, A.M.; Muraca, M. Recent Advances in Mesenchymal Stem Cell Immunomodulation: The Role of Microvesicles. Cell Transplant. 2015, 24, 133-149. [CrossRef]

19. Lai, R.C.; Yeo, R.W.Y.; Lim, S.K. Mesenchymal stem cell exosomes. Semin. Cell Dev. Biol. 2015, 40, 82-88. [CrossRef]

20. Fouraschen, S.M.; Pan, Q.; de Ruiter, P.; Farid, W.R.; Kazemier, G.; Kwekkeboom, J.; Ijzermans, J.N.; Metselaar, H.J.; Tilanus, H.W.; De Jonge, J.; et al. Secreted Factors of Human Liver-Derived Mesenchymal Stem Cells Promote Liver Regeneration Early after Partial Hepatectomy. Stem Cells Dev. 2012, 21, 2410-2419. [CrossRef]

21. Chiabotto, G.; Pasquino, C.; Camussi, G.; Bruno, S. Molecular Pathways Modulated by Mesenchymal Stromal Cells and Their Extracellular Vesicles in Experimental Models of Liver Fibrosis. Front. Cell Dev. Biol. 2020, 8, 594794. [CrossRef]

22. Bruno, S.; Pasquino, C.; Sanchez, M.B.H.; Tapparo, M.; Figliolini, F.; Grange, C.; Chiabotto, G.; Cedrino, M.; Deregibus, M.C.; Tetta, C.; et al. HLSC-Derived Extracellular Vesicles Attenuate Liver Fibrosis and Inflammation in a Murine Model of Nonalcoholic Steatohepatitis. Mol. Ther. 2020, 28, 479-489. [CrossRef]

23. Nojima, H.; Freeman, C.M.; Schuster, R.M.; Japtok, L.; Kleuser, B.; Edwards, M.J.; Gulbins, E.; Lentsch, A.B. Hepatocyte exosomes mediate liver repair and regeneration via sphingosine-1-phosphate. J. Hepatol. 2016, 64, 60-68. [CrossRef]

24. Ferroni, O.; Tassinari, R.; Cavallini, C.; Taglioli, V.; Olivi, E.; Ventura, C.E. Il liofilizzato di fegato di suino Neorland ${ }^{\circledR}$ è fonte di esosomi ben conservati e biologicamente attivi su cellule staminali umane. La Med. Biol. 2019, 1, 3-9.

25. Donato, M.T.; Tolosa, L.; Gómez-Lechón, M.J. Culture and Functional Characterization of Human Hepatoma HepG2 Cells. Methods Mol. Biol. 2015, 1250, 77-93. [PubMed]

26. Gugjoo, M.B.; Amarpal, A.; Sharma, G.T. Mesenchymal stem cell basic research and applications in dog medicine. J. Cell. Physiol. 2019, 234, 16779-16811. [CrossRef]

27. Suelzu, C.M.; Conti, V.; Khalidy, Y.; Montagna, S.; Strusi, G.; Di Lecce, R.; Berni, P.; Basini, G.; Ramoni, R.; Grolli, S. Xenobiotic-Free Medium Guarantees Expansion of Adipose Tissue-Derived Canine Mesenchymal Stem Cells both in 3D Fibrin-Based Matrices and in 2D Plastic Surface Cultures. Cells 2020, 9, 2578. [CrossRef]

28. Mora, S.; García-Román, J.; Gómez-Ñañez, I.; García-Román, R. Chronic liver diseases and the potential use of S-adenosyl-1methionine as a hepatoprotector. Eur. J. Gastroen. Hepat. 2018, 30, 893-900. [CrossRef]

29. Castellino, G.; Nikolic, D.; Magán-Fernández, A.; Malfa, G.A.; Chianetta, R.; Patti, A.M.; Amato, A.; Montalto, G.; Toth, P.P.; Banach, M.; et al. Altilix ${ }^{\circledR}$ Supplement Containing Chlorogenic Acid and Luteolin Improved Hepatic and Cardiometabolic Parameters in Subjects with Metabolic Syndrome: A 6 Month Randomized, Double-Blind, Placebo-Controlled Study. Nutrients 2019, 11, 2580. [CrossRef] [PubMed]

30. Clarke, T.C.; Black, L.I.; Stussman, B.J.; Barnes, P.M.; Nahin, R.L. Trends in the use of complementary health approaches among adults: United States, 2002-2012. Natl. Health Stat. Rep. 2015, 79, 1-16.

31. Bailey, R.L.; Gahche, J.J.; Lentino, C.V.; Dwyer, J.; Engel, J.S.; Thomas, P.R.; Betz, J.M.; Sempos, C.T.; Picciano, M.F. Dietary Supplement Use in the United States, 2003-2006. J. Nutr. 2010, 141, 261-266. [CrossRef]

32. Fulgoni, V.L.; Keast, D.R.; Bailey, R.; Dwyer, J. Foods, Fortificants, and Supplements: Where Do Americans Get Their Nutrients? J. Nutr. 2011, 141, 1847-1854. [CrossRef] [PubMed]

33. Lucena, M.I.; Navarro, V.J. Hepatotoxicity Induced by Herbal and Dietary Supplements. Semin. Liver Dis. 2014, $34,172-193$. [CrossRef]

34. Au, J.S.; Navarro, V.J.; Rossi, S. Review article: Drug-induced liver injury-Its pathophysiology and evolving diagnostic tools. Aliment. Pharmacol. Ther. 2011, 34, 11-20. [CrossRef] [PubMed]

35. Andrade, R.J.; López-Ortega, S.; López-Vega, M.C.; Robles, M.; Cueto, I.; Lucena, M.I. Idiosyncratic drug hepatotoxicity: A 2008 update. Expert Rev. Clin. Pharmacol. 2008, 1, 261-276. [CrossRef] [PubMed]

36. Chalasani, N.; Björnsson, E. Risk Factors for Idiosyncratic Drug-Induced Liver Injury. Gastroenterology 2010, 138, 2246-2259. [CrossRef]

37. Bunchorntavakul, C.; Reddy, K.R. Review article: Herbal and dietary supplement hepatotoxicity. Aliment. Pharmacol. Ther. 2013, 37, 3-17. [CrossRef]

38. Dan, Y.Y.; Yeoh, G.C. Liver stem cells: A scientific and clinical perspective. J. Gastroenterol. Hepatol. 2008, 23, 687-698. [CrossRef]

39. Wan, T.-C.; Liu, Y.-T.; Duann, L.-T.; Yu, K.-H.; Chen, C.-M.; Lin, L.-C.; Sakata, R. Effects of animal liver and bile extracts on biochemical values of rat ethanol-induced fatty liver. Anim. Sci. J. 2013, 85, 75-80. [CrossRef]

40. Caplan, A.I. Mesenchymal Stem Cells: Time to Change the Name! STEM CELLS Transl. Med. 2017, 6, 1445-1451. [CrossRef]

41. Caplan, A.I.; Dennis, J.E. Mesenchymal stem cells as trophic mediators. J. Cell. Biochem. 2006, 98, 1076-1084. [CrossRef] 
42. Loneker, A.E.; Faulk, D.M.; Hussey, G.S.; D'Amore, A.; Badylak, S.F. Solubilized liver extracellular matrix maintains primary rat hepatocyte phenotype in-vitro. J. Biomed. Mater. Res. Part A 2016, 104, 1846-1847. [CrossRef] [PubMed]

43. Nhung, T.H.; Nam, N.H.; Nguyen, N.T.K.; Nghia, H.; Van Thanh, N.; Ngoc, P.K.; Van Pham, P. A comparison of the chemical and liver extract-induced hepatic differentiation of adipose derived stem cells. Vitr. Cell. Dev. Biol. Anim. 2015, 51, 1085-1092. [CrossRef]

44. Tolosa, L.; Donato, M.T.; Gómez-Lechón, M.J. General Cytotoxicity Assessment by Means of the MTT Assay. Methods Mol. Biol. 2014, 1250, 333-348. [CrossRef]

45. Sung, S.; Kim, J.; Jung, Y. Liver-Derived Exosomes and Their Implications in Liver Pathobiology. Int. J. Mol. Sci. 2018, 19, 3715. [CrossRef] [PubMed]

46. Masyuk, A.I.; Masyuk, T.V.; LaRusso, N.F. Exosomes in the pathogenesis, diagnostics and therapeutics of liver diseases. J. Hepatol. 2013, 59, 621-625. [CrossRef] [PubMed]

47. Herrera, M.B.; Fonsato, V.; Gatti, S.; Deregibus, M.C.; Sordi, A.; Cantarella, D.; Calogero, R.; Bussolati, B.; Tetta, C.; Camussi, G. Human liver stem cell-derived microvesicles accelerate hepatic regeneration in hepatectomized rats. J. Cell. Mol. Med. 2010, 14, 1605-1618. [CrossRef] [PubMed] 